Original Research Paper

\title{
Does Iron Modulate Cytokine Production by Desferrioxamine Treated Mononuclear Cells?
}

\author{
Hanna Bessler and Meir Djaldetti \\ Laboratory for Immunology and Hematology Research, Rabin Medical Center, \\ Hasharon Hospital, Petah Tiqva and the Sackler School of Medicine, Tel Aviv University, Ramat Aviv, Israel
}

Article history

Received: 08-09-2017

Revised: 12-11-2017

Accepted: 05-01-2018

Corresponding Author:

Hanna Bessler,

Laboratory for Immunology and Hematology Research,

Rabin Medical Center,

Hasharon Hospital,

7, Keren Kayemet St, Petah

Tiqva, Israel

Tell: $972-3-9372480$

Fax: 972-3-9372388

E-mail: hannab@clalit.org.il

\begin{abstract}
Iron is an essential element for maintaining the normal function of cellular and multicellular organisms and it is closely associated with inflammation and immunity. Macrophages and lymphocytes play an important role in its homeostasis. Hereby we have evaluated cytokine production by iron depleted and iron supplemented human peripheral blood mononuclear cells (PBMC) from healthy adult donors. Non-stimulated or stimulated PBMC (lipopolysaccharide-LPS or phorbol-myristate acetatePMA and ionomycin) were incubated for $24 \mathrm{~h}$ without or with desferrioxamine (DFO) and the quantity of TNF $\alpha$, IL-1 $\beta$, IL-6, IFN $\gamma$, IL-2, IL-10 and IL-1ra in the supernatants was evaluated using ELISA kits. In addition, cytokine levels were determined in supernatants of cultures to which DFO was added for $2 \mathrm{~h}$ followed by $24 \mathrm{~h}$ of incubation with iron. The secretion of IL-1 $\beta$, IL- 6 and IL-1ra by non-stimulated PBMC and that of IL-1 $\beta$ by LPS-stimulated cells was dose-dependently enhanced following incubation with increasing concentrations of DFO between 25 and $100 \mu \mathrm{M}$. On the other hand LPS-induced production of IL-10 and PMA/ionomycin stimulated IL-2 and IFN $\gamma$ secretion was dose dependently reduced. The inhibited IFN $\gamma$, IL-2 and IL-10 secretion by stimulated PBMC caused by DFO was reversed after incubation with iron at concentrations similar to those in human serum. However, the inhibition of LPS-induced IL-1ra or IL-1 $\beta$ production induced by DFO was not affected by iron supplementation. The results of the study underline the importance of intra and/or extracellular iron concentration and DFO for the release of inflammatory cytokines by human peripheral blood mononuclear cells.
\end{abstract}

Keywords: Iron, Desferrioxamine, Cytokines, Mononuclear Cells

\section{Introduction}

The potential of iron as a source of strength has been known to the ancient Greeks and it was introduced in the seventeen century as a therapeutic agent for iron deficiency anemia (Powers and Buchanan, 2014). An early, thorough description of the historical events linked to recognition of iron as a medication has been given by Haden in 1938 (Haden, 1938). Eventually, the importance of iron homeostasis in maintenance of normal functions of cellular and multicellular organisms has been increasingly appreciated. It has been shown that it is tightly connected to macrophage activities and particularly to their ability to sequester iron from phagocytized red blood cells reaching the end of their life span (Soares and Hamza, 2016). The passage of iron through the macrophage membrane is rather complicated and under control of a few components, mainly the peptides ferroportin and hepcidin. While ferroportin exports iron from the macrophages, hepcidin, which is synthesized in the liver, blocks iron release from the cells and prevents its absorption from duodenal enterocytes with a subsequent development of iron deficiency and anemia (Michels et al., 2015; Ganz and Nemeth, 2015; Grellier et al., 2015; Smith et al., 2013). Likewise, hepcidin and ferroportin mediate the iron flux into bacteria resulting in disturbances in bacterial growth (Ward et al., 2011), whereas iron accumulation in the macrophages is the base of their bacteriostatic capacity (Recalcati et al., 2012). Alterations of these peptides' function will result either in iron depletion or iron overload, 
conditions both noxious to the activity of almost all systems, including maintenance of normal immune balance. It has been shown that iron deficiency may decrease immunoglobulin levels, alter T-lymphocyte lineage development and decrease generation of cytokines such as TNF $\alpha$ and IL-2 by activated macrophages (Baker and Ghio, 2009; Hughes and Kelly, 2006). Ekiz et al. (2005) have examined the impact of iron deficiency anemia on children's immune status and have found that the mean IL-6 level, the percentage of monocytes and neutrophils with oxidative burst and phagocytic activity, as well as the IgG4 level, were significantly lower than those in the control group. Iron reduction has been found to be the reason for fatigue and impaired performance in 3\% of 41 athletes being under intensive training (Reid et al., 2004). In a profound search encompassing six studies with a total of 1,422 individuals, Tansarli et al. (2013) have concluded that subjects with iron deficiency may be more susceptible to infections than those with normal serum iron values. Noticeable, infections and inflammations promote hepcidin production with a consequent decrease in serum iron levels (Ganz and Nemeth, 2015). A similar mechanism has been suggested for explanation of lassitude experienced by the majority of patients receiving radiation therapy. Radiation triggers generation of the proinflammatory cytokines IL-1, IL-6 and IL-22 ensuing in inflammation that stimulates production of hepcidin. The current study was initiated to evaluate the effect of iron on cytokine production by human peripheral blood mononuclear cells (PBMC). Since PBMC contain a certain amount of iron, we first attempted to deplete their iron content with desferrioxamine (DFO) and examined the production of TNF $\alpha$, IL-1 $\beta$, IL-6, IL-1ra, IL-10, IL-2 and IFN $\gamma$ by non-stimulated or stimulated PBMC. The generation of the same cytokines was evaluated following addition of iron to DFO treated cells.

\section{Materials and Methods}

\section{Cell Preparation}

Peripheral blood mononuclear cells (PBMC) were obtained from venous blood withdrawn from blood bank donors after obtaining an informed consent. The cells were separated by Lymphoprep-1077 (Axis-Shield PoC AS, Oslo, Norway) gradient centrifugation. The cells were washed twice in phosphate buffered saline (PBS) and suspended in RPMI-1640 medium (Biological Industries, Beith Haemek, Israel) containing $1 \%$ penicillin, streptomycin and nystatin, $10 \%$ heat inactivated fetal calf serum (FCS) and was designated as complete medium (CM).

\section{Desferrioxamine Preparation}

Desferrioxamine mesylate (DFO) (Desferal, Novartis Pharma, Switzerland) was freshly dissolved in saline at a concentration of $10 \mathrm{mM}$ and further dilutions were prepared in saline. DFO was added to cultures at a final volume $10 \mu \mathrm{L} \mathrm{mL}^{-1}$.

\section{Effect of DFO on Cell Viability}

About $0.1 \mathrm{~mL}$ of PBMC suspension $\left(2 \times 10^{6} / \mathrm{ml}\right.$ in $\mathrm{CM})$ was added to each of 96 well plates. DFO was supplemented at concentrations of $0,25,50$ and $100 \mu \mathrm{M}$. The plates were incubated for $24 \mathrm{~h}$ at $37^{\circ} \mathrm{C}$ in a humidified atmosphere containing $5 \% \mathrm{CO}_{2}$. At the end of the incubation period $0.1 \mathrm{~mL}$ of $10 \%$ trypan blue dye was added to each well and viable, as well as dead cells were counted.

\section{Effect of DFO on Cytokine Production}

$0.8 \mathrm{ml}$ of PBMC $\left(2 \times 10^{6} / \mathrm{ml}\right.$ of $\left.\mathrm{CM}\right)$ was incubated without or with LPS (100 ng $\mathrm{mL}^{-1}$, Sigma Israel) or PMA/ionomycin (1 and $0.5 \mu \mathrm{g} \mathrm{mL} \mathrm{m}^{-1}$, Sigma, Israel). DFO was added at the onset of cultures at concentrations of 25, 50 and $100 \mu \mathrm{M}$. Control cultures were incubated without DFO. The cultures were maintained for $24 \mathrm{~h}$ at $37^{\circ} \mathrm{C}$ in a humidified atmosphere containing $5 \% \mathrm{CO}_{2}$. At the end of the incubation period the cells were removed by centrifugation at $1500 \mathrm{rpm}$ for $10 \mathrm{~min}$., the supernatants were collected and kept at $-70^{\circ} \mathrm{C}$ until assayed for cytokine content.

\section{Effect of DFO and Iron on Cytokine Production}

PBMC $\left(2 \times 10^{6} / \mathrm{ml}\right.$ of $\left.\mathrm{CM}\right)$ were incubated without or with $100 \mu \mathrm{M}$ DFO for $2 \mathrm{~h}$ at $37^{\circ} \mathrm{C}$ in a humidified atmosphere containing $5 \% \quad \mathrm{CO}_{2}$ At the end of the incubation period the cells were sedimented by centrifugation at $1500 \mathrm{rpm}$ for $10 \mathrm{~min}$ and twice washed with saline. Afterwards, the cells were suspended in CM and $0.8 \mathrm{~mL}$ aliquots were seeded in 24 well plates and incubated in the absence or presence of iron-hydroxide sucrose solution (Venofer, Vifor, International, St. Gallen, Switzerland) at 100 and 200 $\mu \mathrm{g} \mathrm{dL}^{-1}$, without or with either LPS $\left(100 \mathrm{ng} \mathrm{mL}{ }^{-1}\right)$ or PMA/ionomycin $\left(1 \mu \mathrm{g}\right.$ and $\left.0.5 \mu \mathrm{g} \mathrm{mL}^{-1}\right)$ as described above. The cultures were maintained for $24 \mathrm{~h}$ at $37^{\circ} \mathrm{C}$ in a humidified atmosphere containing $5 \% \mathrm{CO}_{2}$. The cells were removed by centrifugation and the supernatants were collected and kept at $-70^{\circ} \mathrm{C}$ until assayed for cytokines content.

\section{Cytokine Content in the Supernatants}

The concentration of the following cytokines: TNF $\alpha$, IL-1 $\beta$, IL-6, IFN $\gamma$, IL-2, IL-10 and IL-1ra in the supernatants was tested using ELISA kits specific for these cytokines (Biosource International, Camarillo, CA) as detailed in the guide line provided by the manufacturer. The detection levels of these kits were: 15 $\mathrm{pg} / \mathrm{ml}$ for IL-6 and $30 \mathrm{pg} / \mathrm{ml}$ for the remaining ones. 


\section{Statistics}

A linear mixed model with repeated measures and the assumption of Compound Symmetry (CS) was used to assess the effects of DFO, its concentration and cell line on cytokine levels. SAS vs 9.4 was used for this analysis. Paired t-test was applied to compare between the level of cytokines produced with various concentrations of DFO and iron and that found in control cultures. Probability values of $p<0.05$ were considered as significant. The results are expressed as mean \pm SEM.

\section{Results}

\section{Effect of DFO on PBMC Viability}

The number of viable or dead cells counted by trypan blue dye exclusion following $24 \mathrm{~h}$ of incubation of PBMC without or with $100 \mu \mathrm{M}$ of DFO did not differ significantly $(115 \pm 4.6$ vs $110 \pm 3.7$ for live cells, respectively and $9 \pm 1.25$ vs $10 \pm 1.1$ for dead cells, respectively).

\section{Effect of DFO on Pro-Inflammatory Cytokine} Secretion

\section{$T N F \alpha$}

The secretion of TNF $\alpha$ by non-stimulated (spontaneous) or LPS stimulated PBMC was not affected by $24 \mathrm{~h}$ of incubation with DFO at concentrations between 25 and $100 \mu \mathrm{M}\left(\mathrm{F}_{3,18}=0.52, \mathrm{p}=0.67\right.$ and $\mathrm{F}_{3,18}=$ $0.81, \mathrm{p}=0.5$, respectively, Table 1$)$.

\section{$I L-1 \beta$}

A dose dependent stimulation of IL-1 $\beta$ production by non-stimulated or LPS-stimulated PBMC was found following $24 \mathrm{~h}$ of incubation with DFO at concentrations as indicated $\left(\mathrm{F}_{3,18}=4.85, \mathrm{p}=0.0135 ; \mathrm{F}_{3,18}=8.54, \mathrm{p}=\right.$ 0.001 , respectively). At DFO concentrations of $50 \mu \mathrm{M}$ and $100 \mu \mathrm{M}$ the production of IL-1 $\beta$ by non-stimulated PBMC increased by $35 \%(\mathrm{NS})$ and $54 \% \quad(\mathrm{p}<0.05)$ respectively and by LPS-stimulated cells by $24 \%$ ( $\mathrm{P}=$ $0.025)$ and $31 \%(\mathrm{P}<0.001)$, respectively (Table 1$)$.

\section{IL-6}

DFO caused a dose dependent increase in spontaneous production of IL-6 $\left(\mathrm{F}_{3,18}=7.45, \mathrm{p}=\right.$ $0.0019)$, whereas that induced by LPS was not affected $\left(\mathrm{F}_{3,18}=0.23, \mathrm{p}=0.877\right)$. At $\mathrm{DFO}$ concentrations of $50 \mu \mathrm{M}$ and $100 \mu \mathrm{M}$ the secretion of IL- 6 was elevated by $33 \% \mathrm{p}<0.05)$ and $63 \%(\mathrm{p}<0.01)$, respectively (Table 1$)$.

\section{$I F N \gamma$}

While the secretion of IFN $\gamma$ by non-stimulated PBMC was not affected by incubation with $\mathrm{DFO}\left(\mathrm{F}_{3,18}=\right.$ $1.17, \mathrm{p}=0.349)$, that induced by PMA/ionomycin was dose dependently reduced by increasing concentrations of DFO $\left(\mathrm{F}_{3,18}=6.62, \mathrm{p}<0.005\right)$. The production of IFN $\gamma$ was inhibited by $17.5 \%(\mathrm{p}=0.006)$ and by $20 \%(\mathrm{p}=$ 0.012 ) at DFO concentrations of $50 \mu \mathrm{M}$ and $100 \mu \mathrm{M}$, respectively (Table 2 ).

\section{$I L-2$}

IL-2 production by non-stimulated PBMC was low and was not affected by DFO $\left(\mathrm{F}_{3,18}=1.31, \mathrm{p}=0.301\right)$. The production of IL-2 by PMA/ionomycinstimulated cells was reduced by increasing concentrations of DFO $\left(\mathrm{F}_{3,18}=3.48, \mathrm{p}<0.05\right)$ reaching statistical significance at $100 \mu \mathrm{M}$ of DFO only $(17 \%$ inhibition, $\mathrm{p}=0.006$, Table 2).

Table 1: Effect of DFO on pro-inflammatory cytokine production

\begin{tabular}{|c|c|c|c|c|c|c|c|c|c|c|}
\hline \multirow[b]{3}{*}{ DFO $\mu \mathrm{M}$} & \multicolumn{10}{|l|}{ Spontaneous } \\
\hline & \multicolumn{2}{|c|}{$\mathrm{TNF} \alpha, \mathrm{ng} / \mathrm{ml}(\mathrm{n}=7)$} & \multicolumn{2}{|c|}{$\mathrm{IL}-1 \beta, \mathrm{ng} / \mathrm{ml}(\mathrm{n}=7)$} & \multicolumn{2}{|c|}{ IL-6, ng/ml $(\mathrm{n}=7)$} & \multicolumn{2}{|c|}{$\mathrm{IFN} \gamma, \mathrm{ng} / \mathrm{ml}(\mathrm{n}=7)$} & \multicolumn{2}{|c|}{$\mathrm{IL}-2, \mathrm{ng} / \mathrm{ml}(\mathrm{n}=7)$} \\
\hline & Mean \pm SEM & $\mathrm{P}^{*}$ & Mean \pm SEM & $\mathrm{P}^{*}$ & Mean \pm SEM & $\mathrm{P} *$ & Mean \pm SEM & $\mathrm{P} *$ & Mean \pm SEM & $\mathrm{P}^{*}$ \\
\hline 0 & $0.28 \pm 0.05$ & & $1.19 \pm 0.06$ & & $7.96 \pm 1.60$ & & $0.82 \pm 0.23$ & & $0.35 \pm 0.02$ & \\
\hline 25 & $0.27 \pm 0.06$ & NS & $1.35 \pm 0.17$ & NS & $9.98 \pm 2.01$ & NS & $0.61 \pm 0.04$ & NS & $0.35 \pm 0.02$ & NS \\
\hline 50 & $0.30 \pm 0.08$ & NS & $1.61 \pm 0.27$ & NS & $10.59 \pm 1.86$ & $<0.05$ & $0.57 \pm 0.03$ & NS & $0.39 \pm 0.03$ & NS \\
\hline \multirow[t]{2}{*}{100} & $0.29 \pm 0.05$ & NS & $1.83 \pm 0.27$ & $<0.05$ & $12.94 \pm 2.18$ & $<0.01$ & $0.60 \pm 0.06$ & NS & $0.36 \pm 0.03$ & NS \\
\hline & \multicolumn{6}{|l|}{ LPS-induced } & \multicolumn{4}{|c|}{ PMA/ionomycin -induced } \\
\hline 0 & $0.88 \pm 0.13$ & & $4.81 \pm 0.59$ & & $22.89 \pm 0.78$ & & $36.66 \pm 5.68$ & & $17.62 \pm 2.02$ & \\
\hline 25 & $0.82 \pm 0.06$ & NS & $5.72 \pm 0.40$ & $=0.07$ & $23.41 \pm 0.65$ & NS & $32.38 \pm 5.52$ & NS & $16.09 \pm 1.88$ & NS \\
\hline 50 & $0.76 \pm 0.05$ & NS & $6.00 \pm .54$ & $<0.05$ & $23.38 \pm 0.53$ & NS & $30.60 \pm 4.81$ & 0.01 & $15.90 \pm 1.78$ & NS \\
\hline 100 & $0.78 \pm 0.08$ & NS & $6.32 \pm 0.53$ & $<0.001$ & $23.18 \pm 0.63$ & NS & $29.27 \pm 4.90$ & 0.01 & $14.59 \pm 2.06$ & 0.01 \\
\hline
\end{tabular}

PBMC were incubated for $24 \mathrm{~h}$ without (spontaneous) or with LPS or PMA/ionomycin in the absence (0) or the presence of DFO at concentrations as indicated. The level of cytokines in the supernatants was tested by ELISA. The results are expressed as Mean \pm SEM of number of experiments as indicated. P* value represents statistically significant difference from cells incubated without DFO. NS - not statistically significant 
Table 2: Effect of DFO on anti-inflammatory cytokine production

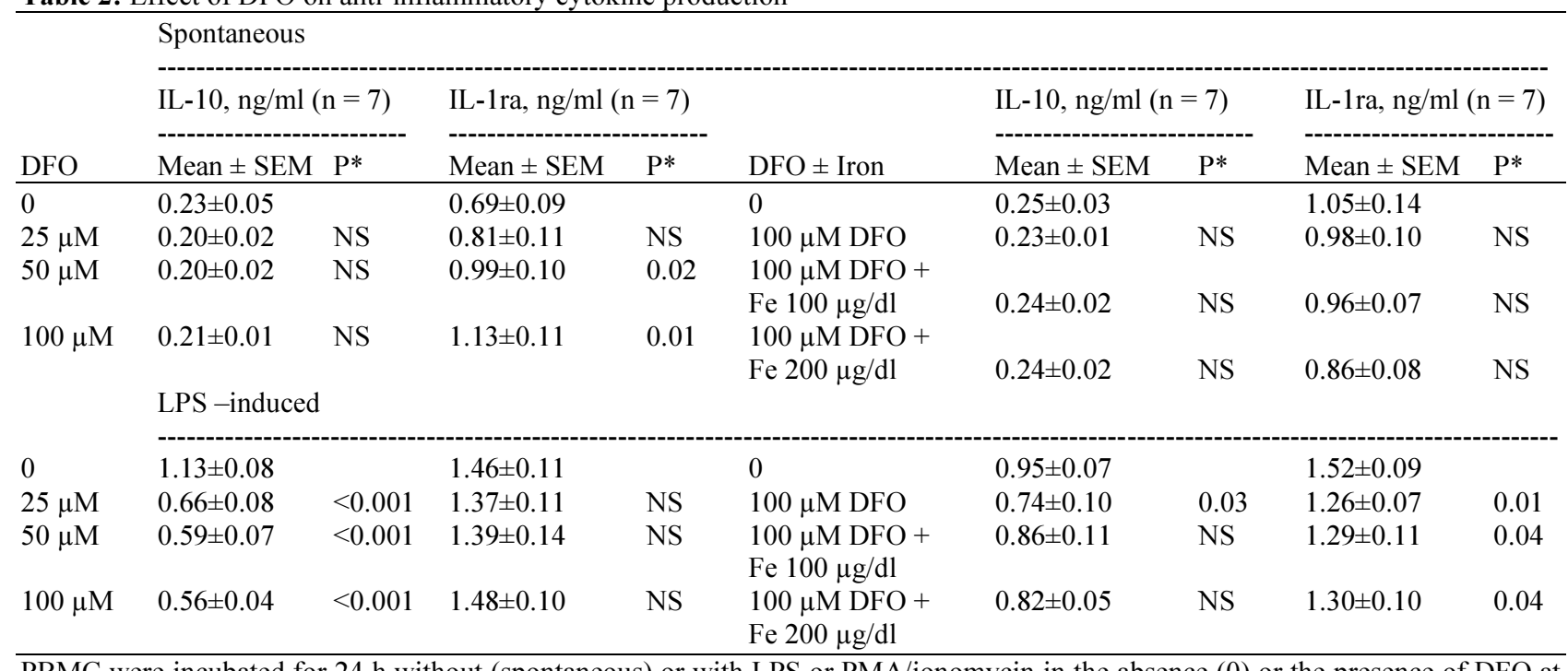

PBMC were incubated for $24 \mathrm{~h}$ without (spontaneous) or with LPS or PMA/ionomycin in the absence (0) or the presence of DFO at concentrations as indicated. The level of cytokines in the supernatants was tested by ELISA. The results are expressed as Mean \pm SEM of number of experiments as indicated. $\mathrm{P}^{*}$ value represents statistically significant difference from cells incubated without DFO. NS - not statistically significant

Table 3: Effect of DFO and iron on cytokine secretion

\begin{tabular}{|c|c|c|c|c|c|c|c|c|c|c|}
\hline \multirow[b]{3}{*}{$\underline{\mathrm{DFO}} \pm$ Iron } & \multicolumn{10}{|l|}{ Spontaneous } \\
\hline & \multicolumn{2}{|c|}{$\mathrm{TNF} \alpha, \mathrm{ng} / \mathrm{ml}(\mathrm{n}=7)$} & \multicolumn{2}{|c|}{$\mathrm{IL}-1 \beta, \mathrm{ng} / \mathrm{ml}(\mathrm{n}=7)$} & \multicolumn{2}{|c|}{$\mathrm{IL}-6, \mathrm{ng} / \mathrm{ml}(\mathrm{n}=7)$} & \multicolumn{2}{|c|}{ IFN $\gamma, \mathrm{ng} / \mathrm{ml}(\mathrm{n}=7)$} & \multicolumn{2}{|c|}{$\mathrm{IL}-2, \mathrm{ng} / \mathrm{ml}(\mathrm{n}=7)$} \\
\hline & Mean \pm SEM & $\mathrm{P}^{*}$ & Mean \pm SEM & $\mathrm{P}^{*}$ & Mean \pm SEM & $\mathrm{P}^{*}$ & Mean \pm SEM & $\mathrm{P}^{*}$ & Mean \pm SEM & $\mathrm{P}^{*}$ \\
\hline 0 & ND & & $1.69 \pm 0.05$ & & $10.57 \pm 1.31$ & & $1.48 \pm 0.11$ & & ND & \\
\hline $100 \mu \mathrm{M}$ DFO & ND & & $1.42 \pm 0.06$ & 0.01 & $9.90 \pm 1.33$ & NS & $1.54 \pm 0.04$ & NS & ND & \\
\hline $\begin{array}{l}100 \mu \mathrm{M} \text { DFO + } \\
\text { Fe } 100 \mu \mathrm{g} / \mathrm{dl} \\
100 \mu \mathrm{M} \text { DFO + }\end{array}$ & ND & & $1.47 \pm 0.08$ & 0.07 & $9.02 \pm 1.43$ & NS & $1.52 \pm 0.09$ & NS & ND & \\
\hline $\mathrm{Fe} 200 \mu \mathrm{g} / \mathrm{dl}$ & $\begin{array}{l}\text { ND } \\
\text { LPS-induced }\end{array}$ & & $1.41 \pm 0.07$ & 0.03 & $8.35 \pm 0.96$ & NS & $\begin{array}{l}1.56 \pm 0.04 \\
\text { PMA/ionomyc }\end{array}$ & $\begin{array}{l}\text { NS } \\
\text { in -ind }\end{array}$ & $\begin{array}{l}\text { ND } \\
\text { aced }\end{array}$ & \\
\hline 0 & $0.65 \pm 0.08$ & & $5.98 \pm 0.32$ & & $16.21 \pm 1.21$ & & $37.97 \pm 4.98$ & & $18.90 \pm 1.93$ & \\
\hline $\begin{array}{l}100 \mu \mathrm{M} \text { DFO } \\
100 \mu \mathrm{M} \text { DFO }\end{array}$ & $0.63 \pm 0.07$ & NS & $6.09 \pm 0.41$ & NS & $16.50 \pm 1.14$ & NS & $31.35 \pm 2.81$ & 0.03 & $17.02 \pm 2.07$ & 0.03 \\
\hline $\begin{array}{l}\mathrm{Fe} 100 \mu \mathrm{g} / \mathrm{dl} \\
100 \mu \mathrm{M} \text { DFO + }\end{array}$ & $0.61 \pm 0.07$ & NS & $5.11 \pm 0.32$ & 0.03 & $16.50 \pm 1.25$ & NS & $35.44 \pm 6.54$ & NS & $18.92 \pm 2.26$ & NS \\
\hline $\mathrm{Fe} 200 \mu \mathrm{g} / \mathrm{dl}$ & $0.66 \pm 0.06$ & NS & $5.40 \pm 0.35$ & NS & $17.20 \pm 1.20$ & NS & $34.25 \pm 2.81$ & NS & $18.38 \pm 0.02$ & NS \\
\hline
\end{tabular}

PBMC were incubated for $2 \mathrm{~h}$ at $37^{\circ} \mathrm{C}$ without (0) or with $100 \mu \mathrm{M}$ DFO. The cells were sedimented by centrifugation, washed twice with saline and incubated for additional $24 \mathrm{~h}$ without (spontaneous) or with LPS or PMA/ionomycin in the presence of iron at concentrations as indicated. The level of cytokines in the supernatants was tested by ELISA. The results are expressed as Mean \pm SEM of number of experiments as indicated. $\mathrm{P}^{*}$ value represents statistically significant difference from cells incubated without DFO or iron (0). NS - not statistically significant. ND - not determined

Effect of DFO on Anti-Inflammatory Cytokine Secretion

\section{IL-10}

IL-10 production by non-stimulated PBMC was not affected significantly by $\operatorname{DFO}\left(\mathrm{F}_{3,18}=0.93, \mathrm{p}=0.44\right)$, while that induced by LPS was dose-dependently inhibited $\left(\mathrm{F}_{3,18}=54.34, \mathrm{p}<0.001\right)$. DFO at 25, 50 and 100 $\mu \mathrm{M}$ reduced IL-10 secretion by 42,48 and $50 \%$ respectively $(\mathrm{p}<0.001$, Table 3$)$

\section{IL-1ra}

The spontaneous generation of IL-1ra by PBMC was dose-dependently stimulated by increasing concentrations of $\operatorname{DFO}\left(\mathrm{F}_{3,18}=9.0, \mathrm{p}<0.001\right)$, whereas that induced by LPS was not significantly affected $\left(\mathrm{F}_{3,18}=\right.$ 
$0.73, \mathrm{p}=0.54)$. At DFO concentrations of 25,50 and 100 $\mu \mathrm{M}$, IL-1ra secretion was enhanced by $20 \%$ (NS), $48 \%$ (p $=0.02)$ and $69 \%(\mathrm{p}=0.011)$, respectively (Table 3$)$.

\section{Effect of DFO and Iron on Cytokine Production}

The spontaneous secretion of TNF $\alpha$, IL-6, IL-2, IFN $\gamma$, IL-10, IL-1ra or the production of TNF $\alpha$, IL-1 $\beta$, IL-6 induced by LPS was not affected by $2 \mathrm{~h}$ of incubation with $100 \mu \mathrm{M}$ of DFO followed by additional $24 \mathrm{~h}$ of incubation without or with 100 or $200 \mu \mathrm{g} / \mathrm{dl}$ iron. However, the secretion of IL- $1 \beta$ by non-stimulated cells was $16 \%$ lower $(p=0.01)$ after $2 \mathrm{~h}$ of incubation with DFO and remained reduced after incubation with iron at $200 \mu \mathrm{g} / \mathrm{dl}(\mathrm{p}=0.03)$. The production of IL-2 and IFN $\gamma$ by PMA/ionomycin-stimulated PBMC was reduced by 10 and $17.5 \%$, respectively $(\mathrm{p}<0.05)$ and following incubation with iron at 100 and $200 \mu \mathrm{g} / \mathrm{dl}$, the production of both cytokines was similar to that of the control (not treated with DFO).

\section{Discussion}

The role of iron in maintaining a normal immune equilibrium has been well established (Latunde-Dada and Young, 1992). Iron depletion may be connected with alteration in cytokine production and aggravation of inflammation, whereas iron excess decreases proinflammatory cytokine secretion and endorses inflammation (Contreras et al., 2016). Pu et al. (2015) have observed that iron depleted piglets treated with iron dextran showed an attenuated release of the proinflammatory cytokines IL-6, TNF $\alpha$, IFN- $\gamma$ and IL- $1 \beta$ in their duodenum and ileum. Similarly, lower IL-2 production by PHA activated lymphocytes has been reported in both iron deficient children (Galan et al., 1992) and mice (Latunde-Dada and Young, 1992). The mechanism of impaired immunity observed in iron deficiency is rather complicated. It is connected with the production and activity of hepcidin (Ganz and Nemeth, 2015; Pu et al., 2015), with decreased secretion of IL-10, a cytokine that is not only anti-inflammatory one, but plays an important role in lymphocyte proliferation and generation of IL-2, IL-12 and IFN $\gamma$ (Kuvibidila et al., 2003). A number of studies have shown that there is a strong linkage between iron homeostasis and the function of macrophages as immune cells (Ward et al., 2011; Nairz et al., 2015; Sullivan, 2007). According to Corna et al. (2010) cytokines polarize macrophages into classically activated (M1) and alternatively activated (M2) subsets expressing different ability for iron accumulation. While M1 macrophages possess high levels of ferritin, M2 cells contain low ferritin level and have the capacity to recycle iron. Conversely, macrophages' iron controls the production of cytokines by these cells (Ganz and Nemeth, 2015). Furthermore, it has been shown that IFN $\gamma$ stimulates M1 activation resulting in decreased immune activity of M2 cells which are tumor associated macrophages (Baer et al., 2016). Jason et al. (2001) have reported that iron deficiency in children is associated with higher percentage of lymphocytes producing IL-6, IFN $\gamma$ and IL4. Since the PBMC used in the present work were obtained from healthy individuals it was conceivable to assume that they contain a certain amount of iron; thus, an attempt was conceived to deplete their iron content using DFO. On the other hand, we had to keep in mind that desferrioxamine (DFO) is linked with monocytes' immune activity and with their capability for cytokine production. In our hands DFO exerted a dose dependent, although different effect on cytokine secretion by both unstimulated and stimulated PBMC. $100 \mu \mathrm{M}$ of DFO induced an increased production of IL-1 $\beta$, IL- 6 and IL1 ra by non-stimulated PBMC, while that of TNF $\alpha$, IL-2 and IFN $\gamma$ was not affected at all. On the other hand, under the effect of DFO stimulated PBMC showed increased secretion of IL-1 $\beta$, whereas that of IL-10, IL-2 and IFN $\gamma$ was inhibited. The reduced production of the anti-inflammatory cytokine IL-10 in iron depleted cells may increase the risk for inflammation and infections in patients with iron deficiency, a cause additional to inadequate bactericidal activity and antibody responses of polymorphonuclear leukocytes, as it has been reviewed by $\mathrm{Lu}$ (2016). Philippe et al. (1992) have reported that exposure of human monocytes to iron chelators results in up-regulation binding of $\mathrm{TNF} \alpha$ to its membrane receptors. However, in cells pretreated with LPS, the binding of TNF $\alpha$ to the cell surface was markedly inhibited (Philippe et al., 1993). Iron depleted mononuclear cells by DFO responded by subdued cell proliferation and IL-2 expression. Pigs treated with DFO showed a pronounced attenuation of IL- 6 production, a cytokine that plays a major role in inflammatory processes (Vlahakos et al., 2012). Topically application of DFO on cutaneous wounds in diabetic rats induced faster healing and elevated significantly the levels of TGF- $\beta 1$ and IL-10, whereas those of TNF $\alpha$ and IL-1 $\beta$ were markedly reduced (Ram et al., 2015). In our experimental setup, the reduced IFN $\gamma$, IL- 2 and IL-10 secretion by DFO stimulated PBMC was reversed after addition of iron, whereas the decrease in IL-1 $\beta$ and IL1ra was not affected by iron supplementation. This phenomenon may be explained either by inability of DFO to completely remove the intracellular iron, or by absence of other factors crucial for maintaining iron homeostasis. Based on the fact that O'Brien-Ladner et al. (2000) have shown that exposure of alveolar macrophages to DFO even for $1 \mathrm{~h}$ caused a significant decrease in intracellular iron concentration, the first possibility seems to be unrelated. The second option appears to be more appropriated considering the numerous factors being essential for iron incorporation, including hepcidin and ferroportin, that cannot be 
implemented for in vitro studies. It is notable that the inhibited IFN $\gamma$ and IL-2 secretion by PMA treated PBMC and that of IL-10 following stimulation with LPS caused by DFO was reversed after incubation with iron at concentrations similar to those in human serum. However, the inhibition of LPS-induced IL1-ra or IL-1 $\beta$ production caused by DFO was not affected by addition of iron at both concentrations. From the results of these experiments it is plausible that the release of various inflammatory cytokines is differently sensitive to intra and/or extra cellular concentration of iron.

\section{Conclusion}

The results of the study indicate that alteration of iron homeostasis in human peripheral blood cells induced by both iron and desferrioxamine may lead to disarray in their capacity for cytokine production affecting the course of inflammatory processes.

\section{Acknowledgment}

The authors would like to extend their gratitude to Ms. Tzippy Shochat, MSc, Statistical Consultant, Rabin Medical Center, Beilinson Hospital, for her valuable assistance in the statistical calculations.

\section{Ethics Approval and Consent to Participate}

Waived for this study by the Ethics Committee of the Rabin medical Center.

\section{Consent for Publication}

Not applicable.

\section{Availability of Data and Material}

The relevant material sources are entered in the text.

\section{Authors' Contributions}

Hanna Bessler: Conceived and carried out the experimental procedures, participated in interpretation of the results and writing the paper.

Meir Djaldetti: Participate in design of the study, analysis of the data and grafting the manuscript.

\section{References}

Baer, C., M.L. Squadrito, D. Laoui, D. Thompson and S.K. Hansen et al., 2016. Suppression of microRNA activity amplifies IFN- $\gamma$-induced macrophage activation and promotes anti-tumor immunity. Nature Cell Biol., 18: 790-802.

DOI: $10.1038 /$ ncb3371
Baker, J.F. and A.J. Ghio, 2009. Iron homoeostasis in rheumatic disease. Rheumatology, 48: 1339-1344. DOI: $10.1093 /$ rheumatology/kep221

Contreras, I., V. Paredes-Cervantes, L.A. GarcaaMiranda, F.B. Pliego-Rivero and J.A. Estrada, 2016. Leukocyte production of IFN- $\gamma$ and TNF- $\alpha$ in 8- to 12-y-old children with low serum iron levels. Nutrition, 32: 546-552.

DOI: $10.1016 /$ j.nut.2015.11.005

Corna, G., L. Campana, E. Pignatti, A. Castiglioni and E. Tagliafico et al., 2010. Polarization dictates iron handling by inflammatory and alternatively activated macrophages. Haematologica, 95: 1814-1822. DOI: $10.3324 /$ haematol.2010.023879

Ekiz, C., L. Agaoglu, Z. Karakas, N. Gurel and I. Yalcin, 2005. The effect of iron deficiency anemia on the function of the immune system. Hematol. J., 5: 579-583. DOI: $10.1038 /$ sj.thj.6200574

Galan, P., H. Thibault, P. Preziosi and S. Hercberg, 1992. Interleukin 2 production in iron-deficient children. Biol. Trace Elem. Res., 32: 421-426. DOI: $10.1007 / \mathrm{BF} 02784628$

Ganz, T. and E. Nemeth, 2015. Iron homeostasis in host defense and inflammation. Nat. Rev. Immunol., 15: 500-510. DOI: 10.1038/nri3863

Grellier, N., G. Deray, A. Yousfi, W. Khodari and R. Bouaita et al., 2015. Functional iron deficiency, inflammation and fatigue after radiotherapy. Bull. Cancer, 102: 780-785.

DOI: $10.1016 /$ j.bulcan.2015.06.001

Haden, R.L. 1938. Historical aspects of iron therapy in anemia. JAMA, 111: 1059-1061. DOI: $10.1001 /$ jama.1938.02790380001001

Hughes, S. and P. Kelly, 2006. Interactions of malnutrition and immune impairment, with specific reference to immunity against parasites. Parasite Immunol., 28: 577-588. DOI: $10.1111 /$ j.1365-3024.2006.00897.x

Jason, J., L.K. Archibald, O.C. Nwanyanwu, M. Bell and R.J. Jensen et al., 2001. The effects of iron deficiency on lymphocyte cytokine production and activation: preservation of hepatic iron but not at all cost. Clin. Exp. Immunol., 126: 466-473. DOI: 10.1046/j.1365-2249.2001.01707.x

Kuvibidila, S., L. Yu, D. Ode, M. Velez and R. Gardner et al., 2003. Effects of iron deficiency on the secretion of interleukin-10 by mitogen-activated and non-activated murine spleen cells. J. Cell Biochem., 90: 278-286. DOI: 10.1002/jcb.10627

Latunde-Dada, G.O. and S.P. Young, 1992. Iron deficiency and immune responses. Scand. J. Immunol. Suppl., 11: 207-209. DOI: $10.1111 / \mathrm{j} .1365-3083.1992 . t b 01654 . x$ 
Lu, S.Y., 2016. Perception of iron deficiency from oral mucosa alterations that show a high prevalence of Candida infection. J. Formos Med. Assoc., 115: 619-627. DOI: 10.1016/j.jfma.2016.03.011

Michels, K., E. Nemeth, T. Ganz and B. Mehrad, 2015. Hepcidin and host defense against infectious diseases. PLoS, Pathog, 11: e4998-e4998. DOI: 10.1371/journal.ppat.1004998

Nairz, M., A. Schroll, E. Demetz, I. Tancevski and I. Theurl et al., 2015. 'Ride on the ferrous wheel'--the cycle of iron in macrophages in health and disease. Immunobiology, 220: 280-294. DOI: 10.1016/j.imbio.2014.09.010

O'Brien-Ladner, A.R., S.R. Nelson, W.J. Murphy, B.M. Blumer and L.J. Wesselius, 2000. Iron is a regulatory component of human IL-1 $\beta$ production support for regional variability in the lung. Am. J. Respir. Cell Mol. Biol., 23: 112-119.

DOI: 10.1165 /ajrcmb.23.1.3736

Philippe, C., B. Fouqueray, J. Perez and L. Baud, 1992. Up-regulation of tumour necrosis factor-alpha receptors on monocytes by desferrioxamine. Clin. Exp. Immunol., 87: 499-503. DOI: $10.1111 /$ j.1365-2249.1992.tb03026.x

Philippe, C., P. Roux-Lombard, B. Fouqueray, J. Perez and J.M. Dayer et al., 1993. Membrane expression and shedding of tumour necrosis factor receptors during activation of human blood monocytes: Regulation by desferrioxamine. Immunology, 80: 300-305.

Powers, J.M. and G.R. Buchanan, 2014. Diagnosis and management of iron deficiency anemia. Hematol Oncol. Clin. North Am., 28: 729-745. DOI: $10.1016 /$ j.hoc.2014.04.007

Pu, Y., B. Guo, D. Liu, H. Xiong and Y. Wang et al., 2015. Iron supplementation attenuates the inflammatory status of anemic piglets by regulating hepcidin. Biol. Trace Elem. Res., 167: 28-35. DOI: $10.1007 / \mathrm{s} 12011-015-0295-6$

Ram, M., V. Singh, S. Kumawat, D. Kumar and M.C. Lingaraju et al., 2015. Deferoxamine modulates cytokines and growth factors to accelerate cutaneous wound healing in diabetic rats. Eur. J. Pharmacol., 764: 9-21. DOI: 10.1016/j.ejphar.2015.06.029
Recalcati, S., M. Locati, E. Gammella, P. Invernizzi and G. Cairo, 2012. Iron levels in polarized macrophages: Regulation of immunity and autoimmunity. Autoimmun. Rev., 11: 883-889. DOI: 10.1016/j.autrev.2012.03.003

Reid, V.L., M. Gleeson, N. Williams and R.L. Clancy, 2004. Clinical investigation of athletes with persistent fatigue and/or recurrent infections. $\mathrm{Br} \mathrm{J}$. Sports Med., 38: 42-45. DOI: $10.1136 /$ bjsm.2002.002634

Smith, C.L., T.L. Arvedson, K.S. Cooke, L.J. Dickmann and C. Forte et al., 2013. IL-22 regulates iron availability in vivo through the induction of hepcidin. J. Immunol., 191: 1845-1855. DOI: $10.4049 /$ jimmunol.1202716

Soares, M.P. and I. Hamza, 2016. Macrophages and iron metabolism. Immunity, 44: 492-504. DOI: $10.1016 /$ j.immuni.2016.02.016

Sullivan, J.L., 2007. Macrophage iron, hepcidin and atherosclerotic plaque stability. Exp. Biol. Med., 232: 1014-20. DOI: 10.3181/0703-MR-54

Tansarli, G.S., D.E. Karageorgopoulos, A. Kapaskelis, I. Gkegkes and M.E. Falagas, 2013. Iron deficiency and susceptibility to infections: evaluation of the clinical evidence. Eur. J. Clin. Microbiol. Infect. Dis., 32: 1253-1258.

DOI: $10.1007 / \mathrm{s} 10096-013-1877-\mathrm{x}$

Vlahakos, D., N. Arkadopoulos, G. Kostopanagiotou, S. Siasiakou and L. Kaklamanis et al., 2012. Deferoxamine attenuates lipid peroxidation, blocks interleukin-6 production, ameliorates sepsis inflammatory response syndrome and confers renoprotection after acute hepatic ischemia in pigs. Artif Organs., 36: 400-408. DOI: $10.1111 /$ j.1525-1594.2011.01385.x

Ward, R.J., R.R. Crichton, D.L. Taylor, L. Della Corte and S.K. Srai et al., 2011. Iron and the immune system. J. Neural. Trans., 118: 315-328. DOI: $10.1007 / \mathrm{s} 00702-010-0479-3$ 